\title{
Matteo A. Pangallo. Playwriting Playgoers in Shakespeare's Theater. Phila- delphia: University of Pennsylvania Press, 2017. Pp 248. Hardback USD \$59.95. ISBN: 97808122494415.
}

\section{LAURIE ELLINGHAUSEN}

University of Missouri — Kansas City

At first glance, the title of Matteo A. Pangallo's book is somewhat of a puzzle does the gerund 'playwriting' refer to 'playgoers' themselves doing the writing, or does 'playwriting' refer to playwrights representing playgoers on stage, as in the gaping and credulous George and Nell of The Knight of the Burning Pestle? Fortunately, Pangallo's aim — to explore the work of 'amateur' playgoers and argue for their importance to the history of early modern English drama - becomes clear enough in his introduction, even as comical stereotypes of the kind found in Beaumont's play linger in the background and, indeed, lend Pangallo's argument much of its exigency. This book intervenes in scholarly attempts to distinguish amateur and professional playwriting by exploring the dramatic creations of audience members who never sought to professionalize but in fact wrote 'from their position as outsiders ... for an increasingly — though always incompletely closed industry' (3). Pangallo interrogates that putatively 'closed' status by examining the work of writers who, he convincingly argues, cannot be written off as 'amateurs' in the typically dismissive and condescending sense of the term, but whose dramatic contributions invite us to reassess the role of spectators within 'an audience-stage relationship that was intensely dialogic, participatory, and creative' (3).

Over the course of four main chapters, a substantive introduction, and a conclusion, Pangallo explores several different kinds of dramatic invention: playgoers revising their manuscripts (Walter Mountfort's The Launching of the Mary, Arthur Wilson's The Inconstant Lady), writing with special attention to the material business of staging (Robert Yarington's Two Lamentable Tragedies, John Clavell's The Soddered Citizen, William Percy's Mahomet and His Heaven), and composing verse drama (Robert Chamberlain's The Swaggering Damsel, Alexander Brome's The Cunning Lovers, Barnabe Barnes's The Devil's Charter). Each case in its own way demonstrates Pangallo's general observation that these writers embodied 'an understanding of cultural consumption that required collaborative participation' between writer and audience (48). The resulting output confronts a rhetoric of professionalization that often registered in professional playwrights' disdain for and mockery of their audiences. This rhetoric, Pangallo points out, has influenced 
scholarly discourse in the past, which has tended to erect a seemingly immutable distinction between 'professionals' and 'amateurs' and dismiss the contributions of the latter as dilettantish, vainglorious, or just plain bad. Each case Pangallo presents problematizes the assumptions underlying such distinctions by showing how playgoers not only wrote plays of comparable interest and quality, but as they did so, harboured no intention of professionalizing — each writer, that is, maintained their roles as 'spectators', a role that did not compromise their writing but in fact enhanced it.

Before launching into a closer examination of these cases, Pangallo offers a substantial discussion of early modern ideas about playgoers as playwrights in chapter one. Here he leads us into the methodologically tricky territory of audience reception and response, seeking to problematize scholarly notions about the dramatist as 'orchestrator' of audience experience by looking at what contemporaneous sources actually have to say on the subject. These sources — which include the writings of antitheatricalists (such as William Prynne), prose texts defending the theatre (such as Heywood's Apology for Actors), and a wide range of actual plays - supply ample evidence to support the notion that audiences played a more creative and participatory role than the older 'orchestration' theory allows. 'Collaborative participation', of course, could problematize or disrupt the 'orchestrator's' vision as much as serve or expand on it, as we learn in a relation of colourful cases where 'playgoers create[d] drama in the playhouse just as much as watch[ed] it' by enacting performances of their own (47). The creative potential of such instances complicates the views espoused by many texts, written for private theatre audiences, which mocked public theatre audiences as mere rubes lacking in critical awareness or theatrical savvy. Whether professional playwrights liked it or not, theatregoers asserted authority not only in their purchasing choices, but in their influence over how the play was actually experienced at the moment of performance.

This sense of theatrical authority as shared and negotiated, rather than as the exclusive province of the professional playwright/orchestrator, provides the groundwork for the ensuing chapters. Chapter two notes the 'Care and pride' behind playgoers' revisions to their own manuscripts, which exhibit a meticulousness that closely mirrors the care that professionals - with their livings presumably on the line - gave to their own texts. Given that amateurs such as Mountfort and Wilson 'could elect simply to abandon their scripts' but chose to continue working on them, their persistence suggests a level of artistic commitment beyond the 'self-satisfaction and dilettantism' that professionals such as Richard Brome ascribed to amateur playwrights (76). Such commitment, it turns out, extended to 
performance as well. Chapter three treats the cases of playwriting playgoers who, despite their presumed vocational distance from the playhouse, well understood its business and knew how to employ its conventions for their own creative ends. Pangallo makes the case by closely analyzing the stage directions of Clavell, Percy, and Mountfort, with the complicated last case meriting particularly close analysis. Likewise, the verse dramas explored in chapter four reveal playgoers' attunement to the creative potential of the conventions within that genre. These cases necessarily veer away from the business of the material stage toward poetic considerations, such as the ratio of verse to rhyme (in Chamberlain's case), the deliberate use of 'old-fashioned' rhyme and diction to build and advance the action (Brome), and metric variation (Barnes). Here again, the texts exhibit sophisticated choices made not out of ignorance or whimsy, but out of authentic, well-informed efforts to achieve particular dramatic effects.

All of these cases, in their unique ways, illuminate corners of early modern theatrical history that, when examined closely, broaden and diversify the reader's view of the period's creative output and practices. Pangallo's intervention in presumed binaries of professional and amateur, particularly as they relate to class identity (a point Pangallo addresses, 21-2) is important and, for the most part, successful. My slight reservation about Pangallo's approach stems mainly from what at times seems a somewhat rigid and ossified take on professional authorship. His evidence that amateurs were well-informed and productively critical about dramatic practices is convincing. But should the effects of a permeable professional-amateur boundary not also work in the other direction - that is to say, did professional playwrights themselves not also watch plays and thus, at least partially, inhabit the playgoers' perspective in their own art? I think in particular of the perennial speculation that professionals born and raised outside London, such as Shakespeare, regularly viewed the productions of touring companies, particularly the last vestiges of the traveling morality plays; even in London, professionals, we can assume, regularly viewed the productions of other playwrights and that they did not always do so with their 'professional' hats on, but as consumers seeking to be entertained. While Pangallo allows that it is 'possible to think of writers not as entirely professional or entirely amateur but as occupying different positions along a spectrum of professionalization demarcated by experience', the kinds of experience he allows those inhabiting the 'professional' end of the spectrum seems to restrict professionals' motivations to the merely commercial, and unfairly so (13). Pangallo refers to 'some informal training' as a characteristic of the professional, a phrase he does not explain further, but which surely might include playgoing itself (19). None of this is to diminish the importance of the 
pressure Pangallo puts on the category of 'amateur'. But just as the amateur can partake of a professional mode for his own ends, presumably so might the professional adopt the fresh perspective of the playgoer. Perhaps one day another study will show us how; until then, scholars and students of the early modern English stage will benefit greatly from Pangallo's insights into playgoers' creative production, an area that sheds new light on previous scholarly assumptions about professionals, audiences, and everyone inhabiting the grey area in between. 